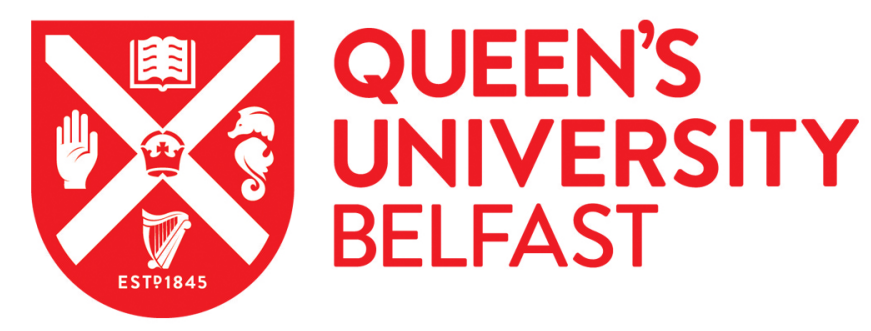

\title{
Design, analysis and performance of a polymer-carbon nanotubes based economic solar collector
}

Kim, S. I., Kissick, J., Spence, S., \& Boyle, C. (2016). Design, analysis and performance of a polymer-carbon nanotubes based economic solar collector. Solar Energy, 134, 251-263.

https://doi.org/10.1016/j.solener.2016.04.019

\section{Published in:}

Solar Energy

\section{Document Version:}

Peer reviewed version

Queen's University Belfast - Research Portal:

Link to publication record in Queen's University Belfast Research Portal

\section{Publisher rights}

(c) 2016 Elsevier Ltd.

This is an open access article published under a Creative Commons Attribution-NonCommercial-NoDerivs License

(https://creativecommons.org/licenses/by-nc-nd/4.0/), which permits distribution and reproduction for non-commercial purposes, provided the author and source are cited.

\section{General rights}

Copyright for the publications made accessible via the Queen's University Belfast Research Portal is retained by the author(s) and / or other copyright owners and it is a condition of accessing these publications that users recognise and abide by the legal requirements associated with these rights.

Take down policy

The Research Portal is Queen's institutional repository that provides access to Queen's research output. Every effort has been made to ensure that content in the Research Portal does not infringe any person's rights, or applicable UK laws. If you discover content in the Research Portal that you believe breaches copyright or violates any law, please contact openaccess@qub.ac.uk. 


\title{
Design, analysis and performance of a polymer-carbon nanotubes based economic solar collector
}

\author{
Sung in Kim ${ }^{1}$, John Kissick ${ }^{1}$, Stephen Spence ${ }^{1}$ and Christine Boyle ${ }^{2}$ \\ ${ }^{1}$ School of Mechanical \& Aerospace Engineering, Queen's University Belfast, UK \\ ${ }^{2}$ Lawell Asphalt Company, UK
}

\begin{abstract}
A low cost flat plate solar collector was developed by using polymeric components as opposed to metal and glass components of traditional flat plate solar collectors. In order to improve the thermal and optical properties of the polymer absorber of the solar collector, Carbon Nanotubes (CNT) were added as a filler. The solar collector was designed as a multi-layer construction with an emphasis on low manufacturing costs. Through the mathematical heat transfer analysis, the thermal performance of the collector and the characteristics of the design parameters were analyzed. Furthermore, the prototypes of the proposed collector were built and tested at a state-of-the-art solar simulator facility to evaluate its actual performance. The inclusion of CNT improved significantly the properties of the polymer absorber. The key design parameters and their effects on the thermal performance were identified via the heat transfer analysis. Based on the experimental and analytical results, the costeffective polymer-CNT solar collector, which achieved a high thermal efficiency similar to that of a conventional glazed flat plate solar panel, was successfully developed.
\end{abstract}

Key-words: Renewable energy, Flat plate, Heat transfer analysis, Efficiency, Cost-effective, Prototype

\section{Introduction}

Renewable energy has been being firstly considered for a sustainable energy future. The exploration for a sustainable way to use energy has been increasingly required due to fossil fuel price increase, climate change and the associated adverse environmental impact. Solar energy can play a significant role to substitute non-renewable energy sources. Solar water heating systems (SWHS), which are one type of valuable and feasible solar energy devices, are very common systems and extensively used in many countries. Recently, the types of solar water heater collectors and their thermal energy performance have been extensively reviewed (Hossain et al. 2011). According to Renewables 2015 Global Status Report (REN21, 2015), cumulative capacity of solar hot water collectors increased by 9 percent in 2014 to reach 406 gigawatts-thermal (GWth) globally. SWHS offer an opportunity to reduce carbon dioxide $\left(\mathrm{CO}_{2}\right)$ emissions from homes and buildings and contribute to achieve the global target of doubling the share of renewable energy in the global energy mix from baseline share of $18 \%$ in 2010 to $36 \%$ by 2030 (IRENA, 2014).

Conventional flat plate solar collectors have been using a metal absorber plate and glass cover to transform solar energy into heat. In this collector, the incident solar energy is converted into heat and transmitted to a transfer medium, such as water. In the design of solar collector components, the transparent cover and the radiation absorber should have more attention. Glass is quite a common choice as a cover for solar thermal devices since it is transparent to the solar radiation and absorbs almost the infrared radiation (IR) re-emitted by the absorber plate. The use of a glass cover has two 
major disadvantages: its weight and fragility during transportation, installation and in service increases shipping, installation and maintenance costs. Typically, the absorber of metals, which have large heat conductivities, is painted with black, solar selective paint to improve collector efficiency, but it causes an extra cost. The total weight and cost of the traditional solar collector is significant due to the high densities and values of metals and glass. Therefore, the use of plastic polymers has been recommended as an alternative material because of their low weight and good resistance against shocks (Dorfling et al., 2010; Tsilingiris, 1999; Wijeysundera and Iqbal, 1991).

According to the demand of cost-effective renewable energy sources, polymers have been investigated for the material of the absorbers and covers of solar collectors. The significant potential of polymer materials for the design and mass fabrication of low cost solar collectors has been shown (Abtahi, 1993; Dorfling et al., 2010; Kudish et al., 2002; Tsilingiris, 1999). Simple plastic film integral collector storage systems have been proposed as low cost solar water heaters (Tsilingiris, 1997). Design optimizations and the effects of the design parameters, such as the insulation thickness, the flow rate, the fluid layer thickness, the air gap thickness, the collector's length and the manifold configurations, on the performance of polymer solar collectors were investigated theoretically and numerically (Cristofari et al., 2002; Mintsa Do Ango et al., 2013; Missirlis et al., 2014). The optimum values of these parameters were proposed and the possibilities of the polymer application in the collector construction were shown. The efficiency and temperature distribution of a honeycomb polycarbonate collector was investigated by using experimental and numerical approaches (Martinopoulos et al., 2010). They observed the relation between the efficiency and the flow patterns inside the collector. Chen et al. (2015) compared full scale polymeric solar collectors with traditional metal solar collectors in the field experiments. The polymer solar collectors showed lower efficiency than the metal solar collectors, however, could decrease significantly the environmental impact. The extensive use of recyclable polymer solar collectors in assembly through on or a few extrusions allows not only a significant cost reduction of the solar water heating systems, but can also minimize the associated installation plumbing.

In this study, in order to improve economic competitiveness, a solar collector was developed by using polymeric components of the transparent cover and the solar radiation absorber. The solar collector was designed as a multi-layer construction with considering the economic manufacturing and selecting an effective material. The performance and characteristics of the solar collector have been analyzed using the mathematical heat transfer modelling. Furthermore, the prototypes of the proposed system were built and tested at a state-of-the-art solar simulator facility to evaluate the actual performance of the developed solar collector.

\section{Solar Collector Design}

2.1 Polymer materials for the solar collector

It is widely known that one of the disadvantages of polymer glazing in solar collector is the degradation under long-lasting exposure to ultraviolet radiation (UVR). Only some of polymer materials are suitable for such a glazing application. The selected properties of the common polymer materials are shown in Table 1. Polycarbonate (PC) is one of the polymers which are stable against UVR. PC has been tested as a material of solar collectors by the researchers. The applicability of PC on the solar collector design has been shown (Chen et al., 2015; Cristofari et al., 2002; Martinopoulos et al., 2010). Additionally, modern PC plates can be produced with a special coating to prevent the penetration of UVR, which causes degradation. The PC plate of $4 \mathrm{~mm}$ thickness was chosen as a transparent cover for the polymer solar collector in the present study. 
The most important part of the solar collector, which determines its efficiency, is the absorber. The major disadvantage of using polymer materials as a collector absorber is their low thermal conductivities as compared to the metal absorbers. In order to increase thermal conductance, heat transfer paths between the absorbing surface and the heat transfer fluid have been maintained as short as possible. Therefore, the current widespread design trend of polymer absorbers is to maintain the maximum contact between the absorbing surface and the heat transfer fluid using as thin layer of polymer as possible (Tsilingiris, 1999).

The thermal conductivities of the common polymers are in the range of 0.1 to $0.5 \mathrm{~W} / \mathrm{m} \cdot \mathrm{K}$ as shown in Table 1. In order to utilize polymers for the absorber of the solar collector, it is necessary to increase their conductivities. The addition of fillers is a way to improve the low thermal conductivity of polymers. Table 2 shows the normal fillers that could be added to polymers. The amount of filler added may need to be in excess of $30 \%$ to achieve a significant improvement in conductivity. However, the addition of large amounts of filler material changes the mechanical properties of the polymer, possibly making it unsuitable for the application (Ebadi-Dehaghani and Nazempour, 2012). Carbon Nanotubes (CNT) have very high thermal conductivity $(2000-6000 \mathrm{~W} / \mathrm{m} \cdot \mathrm{K}$ as listed in Table 2 ) and a super aspect ratio, so allowing good percolation at low concentrations. The concentration of CNT needed to ensure good conductivity in the polymer can be as low as $1.5 \%$, compared to the values for carbon black where much higher loading is necessary (Mark, 2007; Potschke et al., 2003). Owing to their extraordinary thermal conductivity and mechanical properties, CNT have been used in various applications as additives to structural materials (Nanocyl, 2015). The samples of different configurations, such as polycarbonate with $0 \%, 2 \%$ and $4 \%$ CNT concentration by mass, have been produced and tested. The physical properties of the PC samples with $2 \%$ and $4 \%$ CNT were determined through tensile tests and impact tests. The results of tensile tests are summarized in Table 3. It is apparent that the mechanical properties of the polycarbonate deteriorate substantially with the addition of $4 \%$ CNT. The impact test results are recorded in Table 4. The results show that the polycarbonate lost its ductile characteristics and became relatively brittle with the addition of the CNT. This is an undesirable outcome and needs to be compensated in the final design with the use of alternative polymer material to ensure adequate mechanical robustness. Based on the results of the radiation absorption, tensile and impact tests, 2\% CNT impregnated polycarbonate ( $\mathrm{PC}+\mathrm{CNT})$ was selected as a material of the absorber of the solar collector, since it would have significantly improved thermal conductivity and a higher absorbance of solar radiation, while still retaining relatively adequate mechanical properties.

Table 1

Selected properties of some polymers (Chen et al., 2015; Ebadi-Dehaghani and Nazempour, 2012).

\begin{tabular}{lllllll}
\hline Polymer & Title & $\begin{array}{l}\text { Max } \\
\text { Temp. } \\
\left({ }^{\circ} \mathrm{C}\right)\end{array}$ & $\begin{array}{l}\text { Optical } \\
\text { transmission }\end{array}$ & $\begin{array}{l}\text { Thermal } \\
\text { conductivity } \\
(\mathrm{W} / \mathrm{m} \cdot \mathrm{K})\end{array}$ & $\begin{array}{l}\text { UVR } \\
\text { resistance }\end{array}$ & $\begin{array}{l}\text { Hydrolysis } \\
\text { stability }\end{array}$ \\
\hline $\begin{array}{l}\text { Polypropylene } \\
\text { Polycarbonate }\end{array}$ & PP & $90-120$ & $0.7-0.8$ & 0.11 & Poor & Excellent \\
$\begin{array}{l}\text { Polyamide } \\
\text { Polyvinylchloride }\end{array}$ & PA & 130 & $0.8-0.9$ & 0.20 & Good & Poor \\
\hline
\end{tabular}


Table 2

Thermal conductivities of potential polymer filler materials (Ebadi-Dehaghani and Nazempour, 2012).

\begin{tabular}{lc|lc}
\hline Filler & $\begin{array}{c}\text { Conductivity } \\
(\mathrm{W} / \mathrm{m} \cdot \mathrm{K})\end{array}$ & Filler & $\begin{array}{c}\text { Conductivity } \\
(\mathrm{W} / \mathrm{m} \cdot \mathrm{K})\end{array}$ \\
\hline Graphite & $100-400$ & Copper & 483 \\
Carbon Nanotubes & $2000-6000$ & Gold & 345 \\
Carbon Black & $6-174$ & Aluminium & 204 \\
\hline
\end{tabular}

Table 3

Tensile test measurements of the polycarbonate samples.

\begin{tabular}{lccc}
\hline & $\begin{array}{c}\text { Stress at Max Load } \\
\text { (MPa) }\end{array}$ & $\begin{array}{c}\text { \% Strain at Max } \\
\text { Load }\end{array}$ & $\begin{array}{c}\text { Young's modulus } \\
\text { (MPa) }\end{array}$ \\
\hline Polycarbonate & 73 & 197 & 424 \\
Polycarbonate $+2 \%$ CNT & 74 & 195 & 504 \\
Polycarbonate $+4 \%$ CNT & 24 & 11 & 289 \\
\hline
\end{tabular}

Table 4

Impact test measurements of the polycarbonate samples.

\begin{tabular}{lcccc} 
& $\begin{array}{c}\text { Force } \\
(\mathrm{N})\end{array}$ & $\begin{array}{c}\text { Peak } \\
\text { Energy } \\
(\mathrm{J})\end{array}$ & $\begin{array}{c}\text { Total } \\
\text { Energy } \\
(\mathrm{J})\end{array}$ & $\begin{array}{c}\text { Energy/ thickness } \\
(\mathrm{J} / \mathrm{mm})\end{array}$ \\
\hline Polycarbonate & 1832 & 44.6 & 54.7 & 89.2 \\
Polycarbonate + 2\% CNT & 766 & 5.7 & 7.2 & 11.2 \\
Polycarbonate + 4\% CNT & 442 & 0.46 & 4.4 & 0.94 \\
\hline
\end{tabular}

Solar radiation

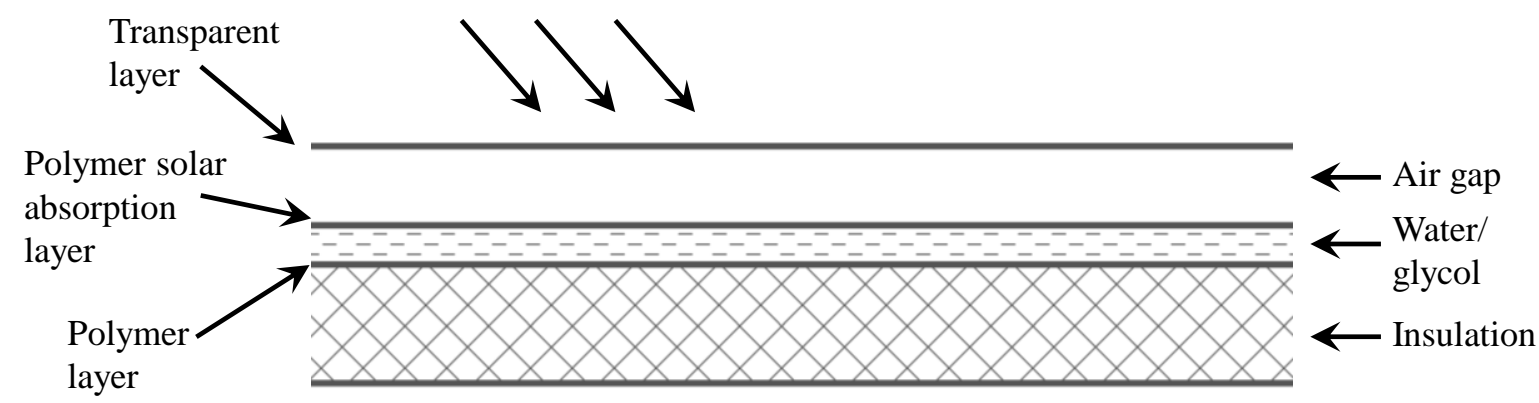

Fig. 1. Schematic diagram of multi-layer polymer solar collector.

\subsection{Construction of the first prototype}

The solar collector was designed as a multi-layer structure consisting of three main polymer layers; (1) An optically transparent layer of plastic glazing above an air gap, (2) A layer of radiation absorbing polymer+CNT separating the air gap above from the water below, (3) A layer of 
polymer+CNT below the water, with polyurethane foam underneath. A schematic representation of the concept of the solar panel design is shown in Fig. 1. In order to absorb additional solar energy, which would transmit the absorption layer and reach the lower surface of the water channel, another $\mathrm{PC}+\mathrm{CNT}$ layer has been used for the lower layer of the water channel on top of the insulation foam.

A satisfactory dispersion of the CNT into the polymer was achieved by the use of a pre-mixed master batch, PLASTICYL ${ }^{\mathrm{TM}}$ PC1501 (Nanocyl S. A., Belgium). PLASTICYL ${ }^{\mathrm{TM}}$ PC1501, which is a family of thin multi-wall carbon nanotubes produced via the catalytic carbon vapor deposition process, is a conductive master batch based on polycarbonate loaded with $15 \%$ of CNT. To achieve the desired concentrations, the necessary quantities of virgin polycarbonate, Marlon FS (Brett Martin Ltd, UK) and CNT master batch were carefully weighed and mixed. The weighing accuracy ensured that the desired CNT concentration was achieved within a tolerance of $0.01 \%$. The screw extruder machine (Killion KN-150) at Queen's University Belfast (operating at $20^{\circ} \mathrm{C}$ above the melting temperature and a mixing time of $20 \mathrm{~min}$ ) was used to produce CNT impregnated polycarbonate with any desired CNT concentration below $15 \%$. Whereas the virgin polycarbonate sheet was transparent in appearance, the $2 \%$ CNT impregnated polycarbonate was a solid black color.

The first prototype solar collector as a sample with dimensions of $500 \mathrm{~mm} \times 500 \mathrm{~mm} \times 75 \mathrm{~mm}$ was constructed to evaluate the effect of CNT addition to the polymer. The diagrammatic cross-sectional view of the prototype solar collector is presented in Fig. 2. A solar collector unit was constructed using clear polycarbonate sheet for the top glazing layer with PC+CNT sheets for the absorbing layer between the air and water as well as the water and insulation. The height of the air gap was $10 \mathrm{~mm}$ and the height of the water channel was $10 \mathrm{~mm}$. Polyurethane insulation of $50 \mathrm{~mm}$ thickness was placed below the water channels. Fig. 3 represents a full module of the first prototype PC+CNT solar collector including manifolds. The water channel was sealed with manifolds added at each end with suitable hose connectors for connection to a test rig. The manifolds were made of Perspex and a suitable solvent adhesive was used to bond all the sections together. Lastly, the solar collector was mounted onto an insulation block and encased in a wood frame for the transportation and installation. The edges of the collector were also insulated. Thermocouples were placed at several points on the surface of the absorber to measure the temperature distribution (as shown in Fig. 4).

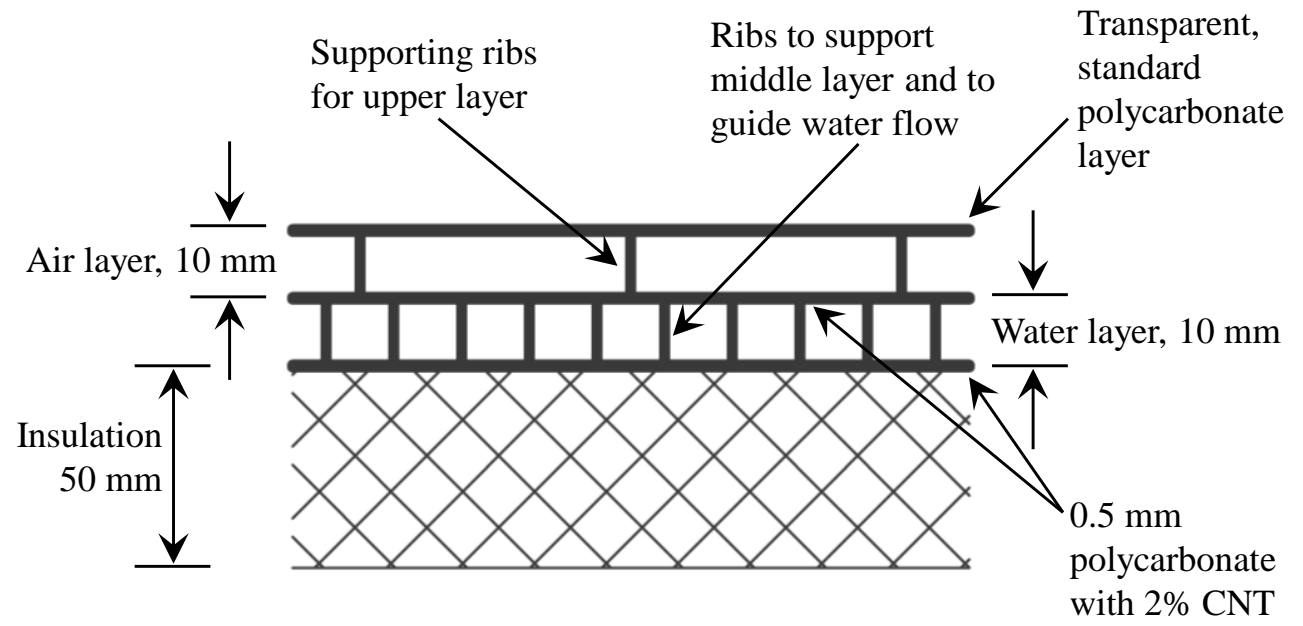

Fig. 2. Cross-sectional view of the tested solar collector. 


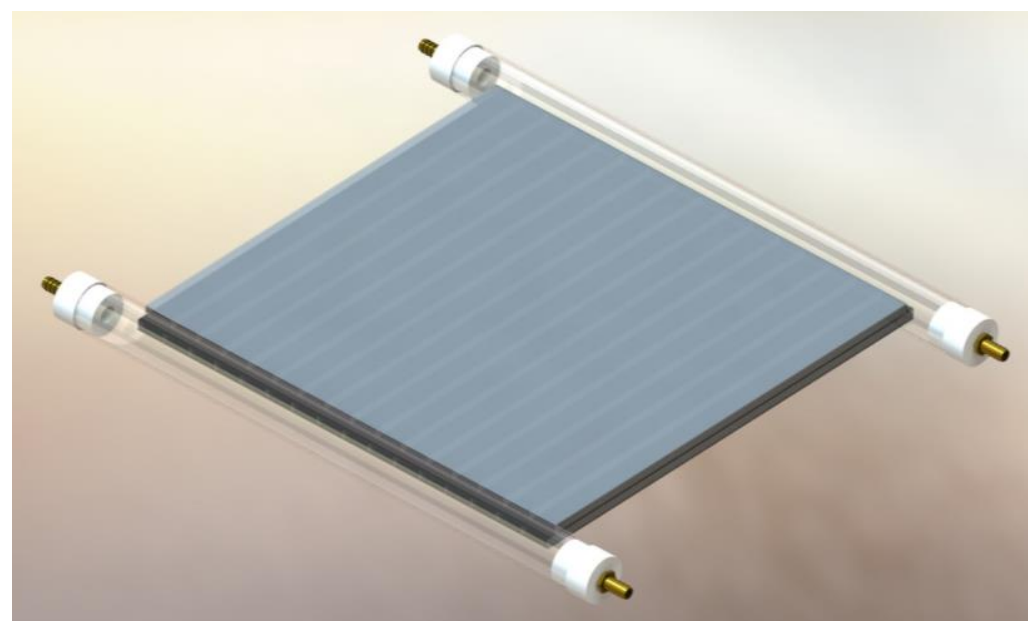

Fig. 3. Solid CAD model of the first prototype solar collector.

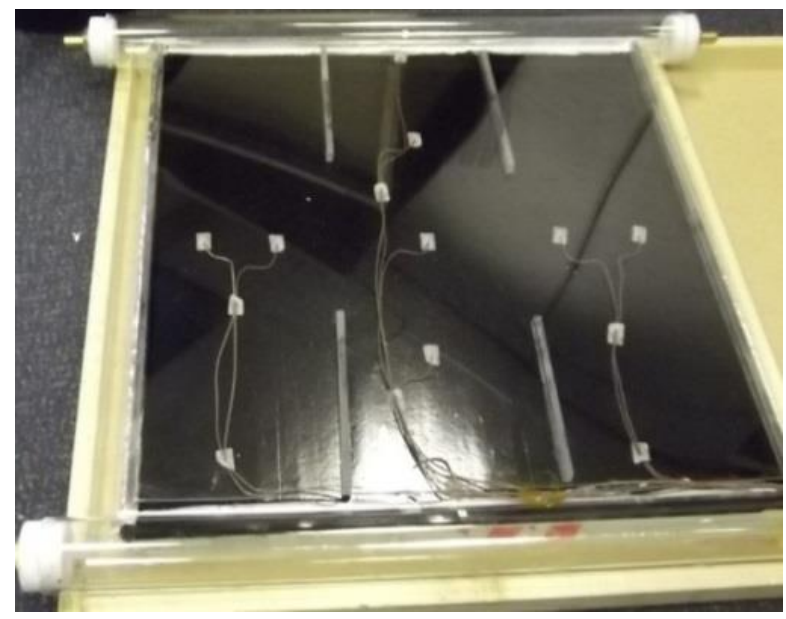

Fig. 4. The first prototype of the proposed PC+CNT solar collector with thermocouples.

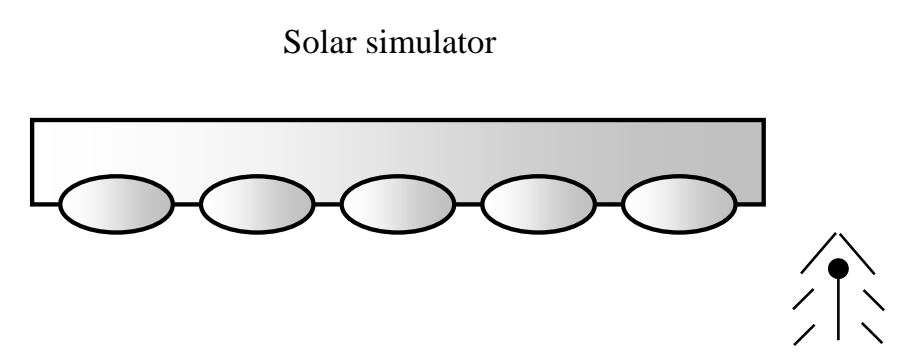

Ambient
Temperature sensor

㐫 Isolation valve

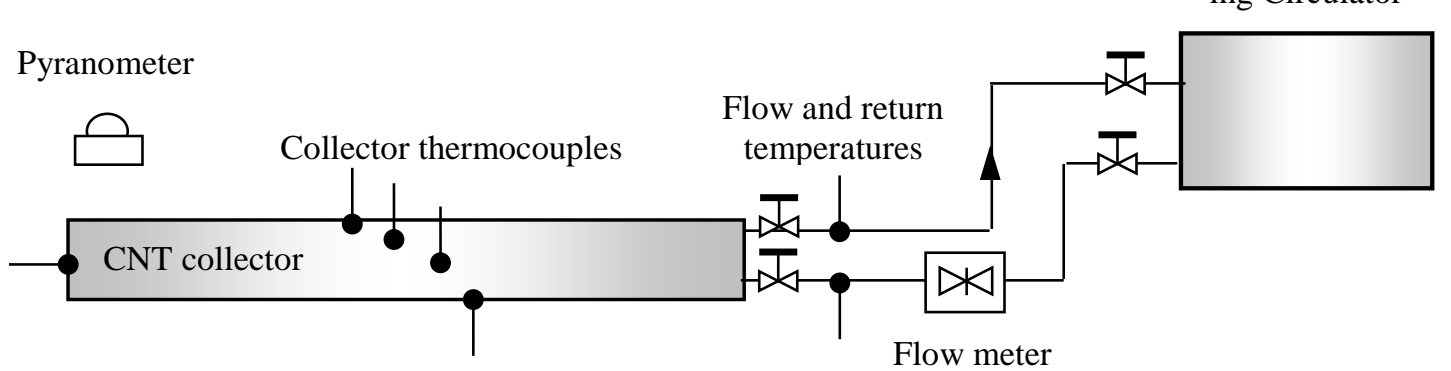

Fig. 5. Schematic detail of test facility and instrumentation (Smyth et al., 2013) 


\section{Test of the First Prototype}

\subsection{Description of the test facility and test method}

The prototype solar collectors were tested using the state-of-the-art indoor solar simulator facility at University of Ulster (Smyth et al., 2013; Zacharopoulos et al., 2009). The solar simulator consisted of a lamp array that produced the required light. The overall dimensions of the solar simulator assembly were $5258 \mathrm{~mm} \times 2617 \mathrm{~mm} \times 2810 \mathrm{~mm}$ (height $\times$ width $\times$ depth). It consisted of high power 35 metal halide lamps arranged in 7 rows of 5 lamps each. Each lamp is equipped with a rotation symmetrical paraboloidal reflector to provide a light beam of high collimation. In order to achieve uniform distribution of light intensity on the test area, a lens was inserted in each lamp to widen the illumination of light. The combination of reflector-characteristics, lens and lamps ensured a realistic simulation of the beam path, spectrum and uniformity. The solar simulator control panel maintained the constant level light intensity automatically on the collector surface via a pyranometer mounted at the center of the collector panel. The maximum available intensity of the light was $1200 \mathrm{~W} / \mathrm{m}^{2}$.

The experimental set up is schematically shown in Fig. 5. The prototype solar collectors were connected to a heating/cooling loop via the JULABO F33-MA Refrigerated/Heating Circulator that could provide a closed flow circuit under constant, controllable conditions. The circulating pump and high heating/cooling capacity guarantee short heat-up and cool-down times. It allowed good control of the inlet water temperature, necessary to conduct accurate and steady solar collector tests. T-type copper-constantan thermocouples, which had an error of $\pm 0.5^{\circ} \mathrm{C}$ between $0^{\circ} \mathrm{C}$ and $70^{\circ} \mathrm{C}$, were used to measure the temperatures of solar collector inlet and outlet water flows, the ambient air and the points on the absorber surface. Manual flow meters were employed to measure water flow rate in the collector heating/cooling loop. All sensors were connected to a stand-alone Delta-T data logger unit to record all measured variables.

The tests were carried out under indoor natural conditions without a fan. Irradiance, temperature and water flow conditions were set to be broadly comparable to those required for testing under BS EN 12975-2:2006. The first test at the solar simulator facility was conducted under the specified constant solar flux of $835 \pm 5 \mathrm{~W} / \mathrm{m}^{2}$. The water flow rate of $0.32 \mathrm{lit} / \mathrm{min}$ was maintained. The used test condition of the flow rate, $76.8 \mathrm{l} /\left(\mathrm{h} \mathrm{m}^{2}\right)$, corresponded to the solar heating system type of the high working fluid rate, larger than $40 \mathrm{l} /\left(\mathrm{h} \mathrm{m}^{2}\right)$, and relatively small temperature increase (up to $15{ }^{\circ} \mathrm{C}$ ), according to the classification of Ladener and Spate (2008). The initial inlet water temperature was set at $20{ }^{\circ} \mathrm{C}$. The inlet water temperature was increased by $5{ }^{\circ} \mathrm{C}$ intervals once the outlet water temperature reached a steady state condition. The test set up was operated for about 2.5 hours prior to taking any measurements in order to allow stabilization of the irradiance levels and ambient temperature. Further stabilization period (typically about $30 \mathrm{~min}$ per each temperature step) were factored into the test programme to ensure that all step measurements would be representative of steady state conditions.

\subsection{Effect of the inclusion of Carbon Nanotubes (CNT)}

In the first test, the prototype $\mathrm{PC}+\mathrm{CNT}$ solar collector and the same-size PC panel (only standard PC sheeting) were simultaneously tested to evaluate the improvement of the properties of the absorber material by the addition of the CNT. For the PC+CNT solar collector, the water temperature increase between inlet and outlet was obvious. However, the PC panel showed heat loss rather than heat gain as the water inlet temperature increased. During the test the accumulation of air within the water channel was observed in the PC panel. The irregular temperature distribution over the PC panel was attributed to the dispersed entrapped air which resulted in uneven heat transfer to the water flow. However, for the $\mathrm{PC}+\mathrm{CNT}$ collector the temperature distributions showed a consistent and reasonable trend; lower surface temperature around the water inlet region and higher surface temperature near the 
water outlet area.

The performance of the solar collectors can be traditionally represented by using the thermal efficiency of the collector. According to Hossain et al. (2011), the amount of solar radiation received by the collector can be expressed by the following equation:

$$
Q_{\text {solar }}=G_{\text {solar }} A_{s}
$$

where $Q_{\text {solar }}$ is the collector heat input in $\mathrm{W}, G_{\text {solar }}$ is a given solar intensity in $\mathrm{W} / \mathrm{m}^{2}, A_{s}$ is the collector area. However, only some amount of the solar radiation penetrate the transparent cover of the collector and are absorbed into the absorber. It can be expressed:

$$
Q_{i}=G_{\text {solar }}(\tau \alpha) A_{s}
$$

where $\tau$ is the transmittance of the glazing cover and $\alpha$ is the absorbance of the absorber. Unavoidably, the thermal energy of the collector at higher temperature is transmitted to the surrounding at lower temperature. The rate of heat loss can be approximately expressed by the overall heat transfer coefficient of the collector and its temperature:

$$
Q_{o}=U_{L} A_{s}\left(T_{c}-T_{a}\right)
$$

where $Q_{o}$ is the heat loss rate in $\mathrm{W}, \mathrm{U}_{\mathrm{L}}$ is the collector overall heat loss coefficient in $\mathrm{W} / \mathrm{m}^{2} \cdot \mathrm{K}, \mathrm{T}_{\mathrm{c}}$ is the average temperature of the collector and $\mathrm{T}_{\mathrm{a}}$ is the ambient temperature. Therefore, the rate of useful energy actually obtained by the collector is the heat loss subtracted from the rate of energy absorbed by the collector:

$$
Q_{u}=Q_{i}-Q_{o}=G_{\text {solar }}(\tau \alpha) A_{s}-U_{L} A_{s}\left(T_{c}-T_{a}\right)
$$

where $Q_{u}$ is the useful energy gain in $\mathrm{W}$. It is difficult to define the collector average temperature. For the convenience, Eq. (4) can be rewritten by using the collector heat removal factor, $F_{R}$ and the water inlet temperature based on Hottel-Whillier-Bliss equation:

$$
Q_{u}=A_{s} F_{R}\left[G_{\text {solar }}(\tau \alpha)-U_{L}\left(T_{i n}-T_{a}\right)\right]
$$

Alternatively, the useful energy gain can be measured by means of the total rate of heat transferred to the water from the collector based on the conservation of energy under the steady condition. It can be calculated with the measured water temperature variations;

$$
Q_{u}=\dot{m} c_{p}\left(T_{\text {out }}-T_{\text {in }}\right)
$$

where $\dot{m}$ is the mass flow rate of the water through the collector. The collector efficiency is defined by the ratio of the collected useful energy from the solar collector divided by the given solar irradiation:

$$
\begin{aligned}
& \eta=\frac{Q_{u}}{Q_{\text {solar }}}=\frac{A_{s} F_{R}\left[G_{\text {solar }} \tau \alpha-U_{L}\left(T_{\text {in }}-T_{a}\right)\right]}{G_{\text {solar }} A_{s}}=\frac{\dot{m} c_{p}\left(T_{\text {out }}-T_{\text {in }}\right)}{G_{\text {solar }} A_{s}} \\
& \eta=F_{R} \tau \alpha-F_{R} U_{L}\left(\frac{T_{\text {in }}-T_{a}}{G_{\text {solar }}}\right)
\end{aligned}
$$

The collector efficiency $\eta$ can be plotted against $\left(\mathrm{T}_{\mathrm{in}}-\mathrm{T}_{\mathrm{a}}\right) / \mathrm{G}_{\text {solar }}$. The slope of this curve, $-F_{R} U_{L}$, represents the rate of heat loss from the collector. Thus, unglazed solar collectors have larger slope than those with cover sheets. The maximum efficiency, $F_{R} \tau \alpha$, on the ordinate mainly relies on the 
optical properties of the collector. The efficiencies of two panels of the first test were compared with the reference of a conventional glazed flat plate solar collector with moderately selective black paint absorber in Fig. 6. By comparing the maximum efficiencies, the improvement of the PC+CNT solar collector performance by adding CNT was more than 2.5 times higher than that of the only PC panel. However, the performance of the PC+CNT collector was still very low compared to the performance of the conventional solar collector. The detailed analysis of the first test results and the suggestion for the improvement follow on from the heat transfer analysis.

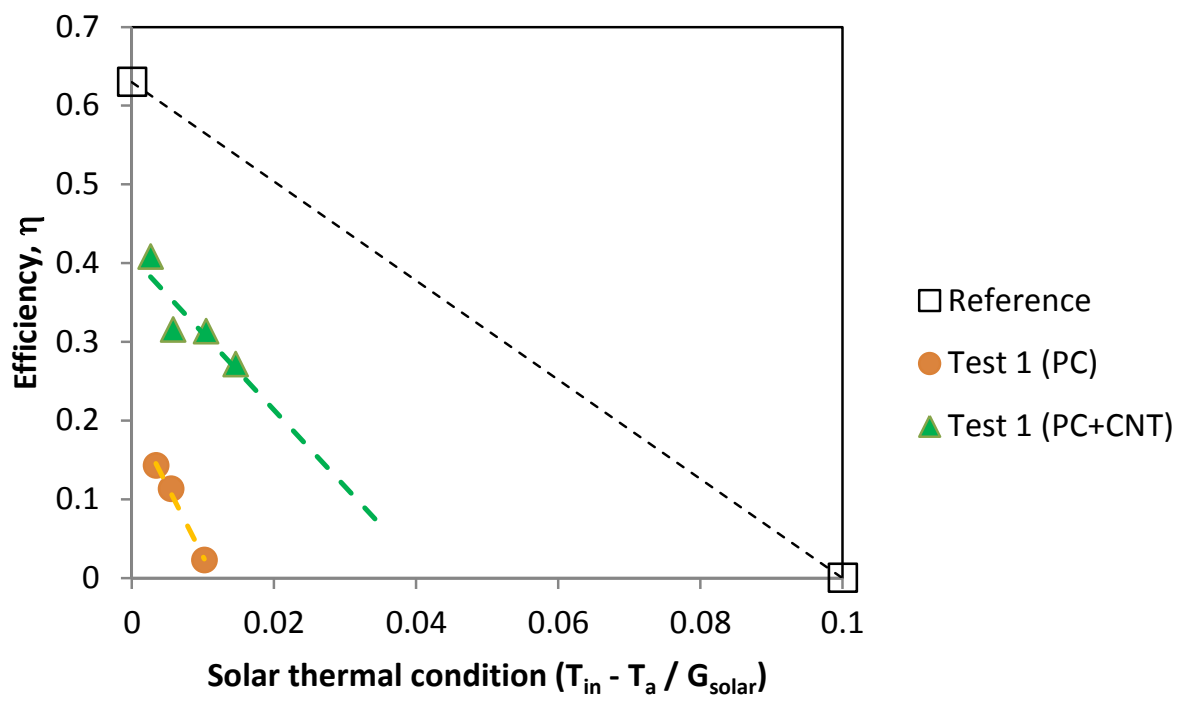

Fig. 6. The efficiencies of the first tested solar collectors.

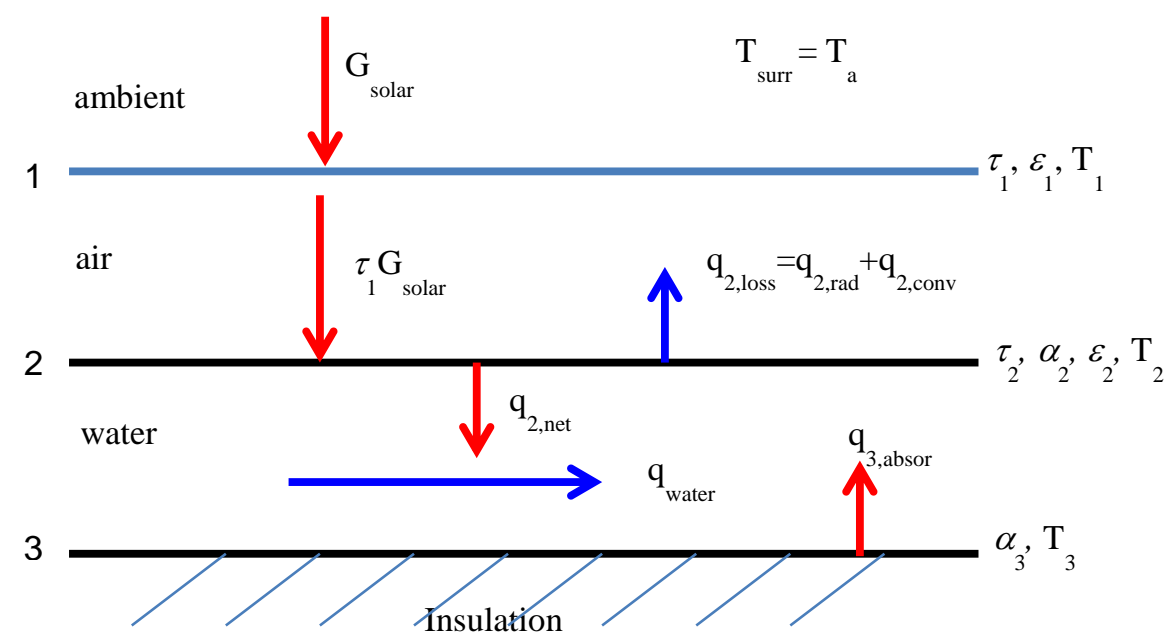

Fig. 7. The net heat transfer in the solar collector. 


\section{Heat Transfer analysis}

\subsection{Heat transfer modelling}

This section describes a mathematical heat transfer model that estimates the effect of key design parameters on the performance of the proposed solar collector. A steady state, one-dimensional heat transfer that solves the coupled radiative and convective energy balances at the solar absorbing layers of the flat plate solar collector was considered. The schematic diagram of the heat transfer in the solar collector was shown in Fig. 7. In the heat transfer analysis, the uniform constant temperature of each layer was assumed. For the air between the layer 1 and layer 2 in Fig. 7, the constant properties of ideal gas air at the mean temperature of these two layers were used. The surrounding temperature $\left(\mathrm{T}_{\text {surr }}\right)$ for the radiation and the ambient temperature $\left(\mathrm{T}_{\mathrm{a}}\right)$ for the convection were assumed to be identical due to the indoor test environment with sufficient stabilization time. The temperature rise of the glazing under the stationary conditions is less than $5{ }^{\circ} \mathrm{C}$ (Mintsa Do Ango et al., 2013). By ignoring the wind chill effect because of no forced flows in the tests, the natural convection loss from the glazing cover is not significant. Thus, the top glazing surface temperature of the solar collector was assumed to be approximately same to the ambient temperature $\left(\mathrm{T}_{1}=\mathrm{T}_{\mathrm{a}}\right)$ under steady state condition.

The amounts of the absorbed heat into the layer 2 and layer 3 (upper and lower boundary of the heat transfer fluid, water) were determined by the optical properties of the material.

$$
q_{2, \text { absor }}=\alpha_{2} \tau_{1} G_{\text {solar }} \quad \text { and } \quad q_{3, \text { absor }}=\alpha_{3} \tau_{2} \tau_{1} G_{\text {solar }}
$$

where $\tau_{1}$ and $\tau_{2}$ were the transmissivities of the first (PC) layer and the second (PC+CNT) layer, $\alpha_{2}$ and $\alpha_{3}$ were the absorptivities of the second and third layers of PC+CNT (here, $\alpha_{2}=\alpha_{3}$ because of the same material) and $\mathrm{G}_{\text {solar }}$ was a given solar radiation intensity. Therefore, the maximum absorbable heat $\left(q_{2, \text { absor }}+q_{3, \text { absor }}\right)$ in the solar collector was mainly determined by the optical properties of the absorber material. In order to gain more solar heat in the collector, higher absorptivity of the absorbing layer is required.

The heat losses from the absorbing layer due to the temperature difference between $T_{1}$ and $T_{2}$ were represented by the two heat transfer mechanisms of radiation and convection. The heat loss by radiation was calculated by Stefan's law which was comprised of the temperatures and emissivities of two parallel gray diffuse plates (Cengel and Ghajar, 2011).

$$
q_{2, \text { rad }}=\frac{\sigma\left(T_{2}^{4}-T_{1}^{4}\right)}{\frac{1}{\varepsilon_{2}}+\frac{1}{\varepsilon_{1}}-1}
$$

The second heat loss was caused by the natural convection due to the temperature difference between the two layers of the air gap. It was determined by the thermodynamic properties of the air ( $k_{\text {air }}, v_{\text {air }}, \operatorname{Pr}$ ) and the geometric parameter, the air gap height, $\mathrm{H}_{1}$.

$$
q_{2, \text { conv }}=k_{\text {air }} N u \frac{T_{2}-T_{1}}{H_{1}}
$$

where, $\quad N u=1+1.44\left[1-\frac{1708}{R a}\right]^{+}+\left[\frac{R a^{1 / 3}}{18}-1\right]^{+}, R a=\frac{g \beta\left(T_{2}-T_{1}\right) H_{1}^{3}}{v_{\text {air }}{ }^{2}} \operatorname{Pr}$ based $\quad$ on the empirical correlation of Hollands et al. (1976). 
The net heat gain at the second layer (the layer 2 in Fig. 7) was able to be obtained by the heat balance:

$$
\begin{aligned}
q_{2, \text { net }} & =q_{2, \text { absor }}-q_{2, \text { rad }}-q_{2, \text { conv }} \\
q_{\text {total }} & =q_{2, \text { net }}+q_{3, \text { absor }}=q_{2, \text { absor }}-q_{2, \text { rad }}-q_{2, \text { conv }}+q_{3, \text { absor }} \\
& =f\left(T_{1}, T_{2}, H_{1}, \text { properties }\right)=f\left(T_{2}\right)
\end{aligned}
$$

The total net heat gain of the solar collector was the sum of the net heat gain of the layer 2 and the absorbed heat of layer 3. As shown in above formulas, this total net heat gain was determined by the temperatures of the layers, thermodynamic and optical properties of the air and materials, and the geometric dimension. If the top layer temperature $\left(\mathrm{T}_{1}\right)$ and the dimension $\left(\mathrm{H}_{1}\right)$ were given and the properties were assumed, the total heat gain, $\mathrm{q}_{\text {total }}$, was determined by only the temperature $\left(\mathrm{T}_{2}\right)$ of the second layer (upper PC+CNT layer). For given dimensions and properties, the total heat gain of the solar collector was ideally maximized when the temperature of the absorbing layer $\left(\mathrm{T}_{2}\right)$ was the same to the top layer temperature $\left(\mathrm{T}_{1}\right)$; no heat loss from the layer 2 to the layer 1 , no heat remained at the absorbing layer, and therefore all the absorbed heat was transferred to the water. When the total absorbed heat was transferred to the water, the water temperature was increased through the solar collector $\left(\mathrm{T}_{\text {out }}>\mathrm{T}_{\text {in }}\right)$. The outlet water temperature could be calculated from the energy conservation.

$$
\begin{aligned}
& q_{\text {total }}=\dot{m} c_{p}\left(T_{\text {out }}-T_{\text {in }}\right) / A_{s}=g\left(T_{\text {out }}\right) \\
& \therefore q_{\text {total }}=q_{2, \text { net }}+q_{3, \text { absor }}=\dot{m} c_{p}\left(T_{\text {out }}-T_{\text {in }}\right) / A_{s} \\
& \Rightarrow \therefore f\left(T_{2}\right)=g\left(T_{\text {out }}\right)
\end{aligned}
$$

Although the heat balance equation (Eq. 14) was concluded, two unknown temperatures $\left(\mathrm{T}_{2}\right.$ and $\left.\mathrm{T}_{\text {out }}\right)$ and the fourth power of temperature $\left(T_{2}^{4}\right)$ in radiation (Eq. 9) made it difficult to solve directly. The temperatures of the absorbing layer $\left(\mathrm{T}_{2}\right)$ and the water outlet $\left(\mathrm{T}_{\text {out }}\right)$ were calculated iteratively. The iterative computation procedure was depicted in the diagram in Fig. 8. For a given water inlet temperature $\left(\mathrm{T}_{\text {in }}\right)$, the water outlet temperature $\left(\mathrm{T}_{\text {out }}\right)$ was initially estimated and then the total heat flux $\left(\mathrm{q}_{\text {total }}\right)$ was calculated from the water temperature rise. The temperature of the absorbing layer $\left(\mathrm{T}_{2}\right)$ was determined to satisfy the heat balance; the total absorbed heat, $f\left(\mathrm{~T}_{2}\right)$, should be equal to the transferred heat, $g\left(\mathrm{~T}_{\text {out }}\right)$, under the restrictive condition of $\mathrm{T}_{2}>\mathrm{T}_{\text {out }}$. If the transferred heat, $g\left(\mathrm{~T}_{\text {out }}\right)$, was greater than the absorbed heat, $f\left(\mathrm{~T}_{2}\right)$, then the water outlet temperature $\left(\mathrm{T}_{\text {out }}\right)$ was reduced and $\mathrm{T}_{2}$ was determined to meet the heat balance. Iteratively $\mathrm{T}_{2}$ was calculated with decreasing $\mathrm{T}_{\text {out }}$ until satisfying $f\left(\mathrm{~T}_{2}\right)=g\left(\mathrm{~T}_{\text {out }}\right)$ and $\mathrm{T}_{2}>\mathrm{T}_{\text {out }}$.

In order to calculate the heat transfer rate in the solar collector, the base optical properties of the proposed material, $\mathrm{PC}+\mathrm{CNT}$, were assumed as shown in Table 5, based on the typical properties of PC. Heat transfer analysis was firstly performed with these assumed base values. The solar intensity, $835 \mathrm{~W} / \mathrm{m}^{2}$, of the given test condition was used for the following calculations. 


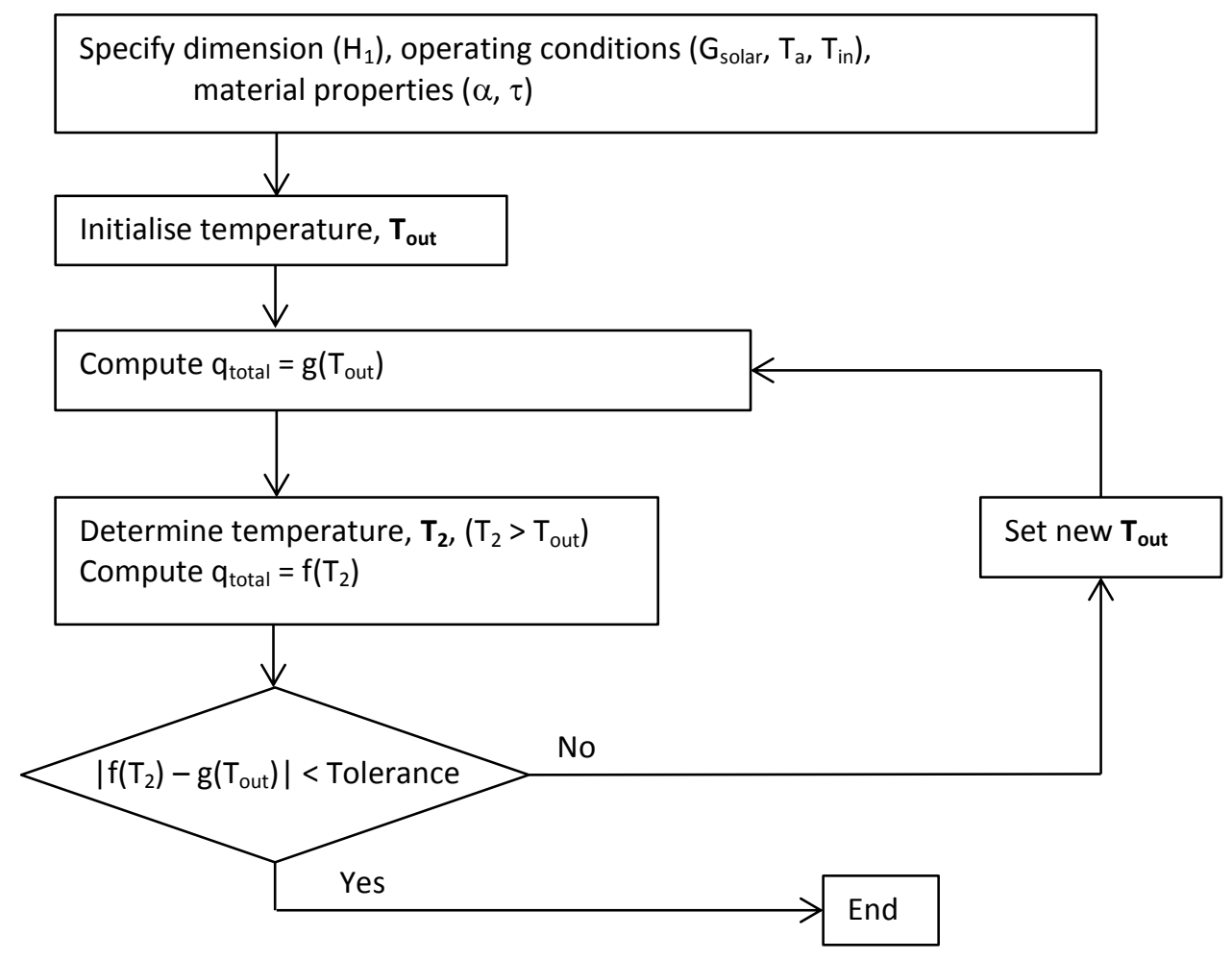

Fig. 8. The flow chart for nonlinear iterative calculation.

Table 5

The assumptions of the optical properties of the materials of the solar collector.

\begin{tabular}{llcc}
\hline \hline & Optical properties & Base values & Higher \\
\hline \multirow{2}{*}{ PC glazing layer } & Solar transmittance, $\tau_{1}$ & 0.85 & \\
& Infrared emissivity, $\varepsilon_{1}$ & 0.5 & \\
\hline \multirow{3}{*}{ PC+CNT upper layer } & Solar absorbance, $\alpha_{2}$ & 0.4 & 0.56 \\
& Solar transmittance, $\tau_{2}$ & 0.4 & 0.4 \\
& Infrared emissivity, $\varepsilon_{2}$ & 0.5 & 0.5 \\
\hline PC+CNT lower layer & Solar absorbance, $\alpha_{3}$ & 0.4 & 0.56 \\
\hline \hline
\end{tabular}

Table 6

Measured temperatures and heat transfer of the first PC+CNT collector.

\begin{tabular}{llllllll}
\hline \hline $\mathrm{T}_{\mathrm{a}}\left({ }^{\circ} \mathrm{C}\right)$ & $\mathrm{T}_{\text {in }}\left({ }^{\circ} \mathrm{C}\right)$ & $\mathrm{T}_{\text {out }}\left({ }^{\circ} \mathrm{C}\right)$ & $\begin{array}{l}\mathrm{q}_{\text {total }}\left(\mathrm{W} / \mathrm{m}^{2}\right) \\
\text { to water }\end{array}$ & $\mathrm{T}_{2}\left({ }^{\circ} \mathrm{C}\right)$ & $\alpha_{2}$ & $\begin{array}{l}\mathrm{q}_{\text {total,a4 }}\left(\mathrm{W} / \mathrm{m}^{2}\right) \\
\text { with } \alpha_{2}=0.4\end{array}$ & $\begin{array}{l}\text { Heat } \\
\text { loss }\end{array}$ \\
\hline 19.44 & 21.64 & 25.08 & 305.38 & 30.85 & 0.358 & 347 & $13 \%$ \\
20.73 & 25.57 & 28.23 & 236.14 & 34.91 & 0.308 & 328 & $28 \%$ \\
20.61 & 29.33 & 31.97 & 234.36 & 38.94 & 0.328 & 306 & $24 \%$ \\
21.13 & 33.34 & 35.63 & 203.29 & & & & \\
\hline \hline
\end{tabular}




\subsection{Estimation of solar absorptivity of the $P C+C N T$ layer and the heat transfer rate from the first test results}

By using the measured temperatures, the optical properties of the PC+CNT layer could be estimated. The measured ambient $\left(\mathrm{T}_{\mathrm{a}}\right)$, water inlet $\left(\mathrm{T}_{\text {in }}\right)$, and water outlet $\left(\mathrm{T}_{\text {out }}\right)$ temperatures of the first PC+CNT collector are listed in Table 6 . The calculated total amounts of heat flux transferred to the water, $\mathrm{q}_{\text {total }}$, using Eq. (13) are also shown in the $4^{\text {th }}$ column of Table 6 . The total amount of heat transferred to the water should be identical with the net heat gain by the absorbing layers under the assumption of no heat loss between the absorbing layers and water. The total net heat gain of the absorbing layers can be obtained by the subtraction of the heat losses of the upper absorbing layer by radiation and natural convection from the solar energy absorbed in both the upper and lower layers of the water channel (Eq. 12). The total heat flux is a function of the temperatures of the layers, the optical properties (e.g. solar absorptivity, $\alpha$, and transmissivity, $\tau$, of the layers), and the geometric parameters (e.g. the height of the air gap, $\mathrm{H}_{1}$ ). By using the measured temperatures and the known dimensions of the collector, the optical properties of the absorbing layer can be estimated. The averaged value of the measured surface temperatures on the absorbing layer $\left(T_{2}\right.$ in Table 6$)$ was used for this estimation. The primary interest must be on the absorptivity of the solar absorption layer of PC+CNT. The solar absorptivity $\left(\alpha_{2}\right)$ of the PC+CNT layer was calculated by using the assumed base values of the properties (Table 5), the obtained total heat flux, $\mathrm{q}_{\text {total }}$, and the measured average surface temperature $\left(T_{2}\right)$. The calculated absorptivity $\left(\alpha_{2}\right)$ is listed in Table 6 . Finally, the solar radiation absorptivity of the $\mathrm{PC}+\mathrm{CNT}$ layer was estimated to be around 0.33 which is more than three times of the polycarbonate absorptivity (typically, 0.09). It is consistent with the measured efficiency of the $\mathrm{PC}+\mathrm{CNT}$ solar collector in the first test as shown in Fig. 6. Therefore, the inclusion of CNT significantly improved the thermal conductivity as well as the solar absorption of the polycarbonate.

Due to the entrapped air, the heat absorbed into the PC+CNT layer was not able to be fully transferred to the water. The relatively small size of panel resulted in the significant edge effect (additional heat losses through the edges of the solar panel). By taking account of these detrimental effects, the potential solar absorptivity of the PC+CNT layer would be higher than 0.33 , which was estimated based on the measured water temperatures. The ideally maximum amount of heat gain, $\mathrm{q}_{\mathrm{total}, \mathrm{a} 4}$, with the assumed solar radiation absorptivity of $\alpha_{2}=0.4$ was estimated using Eq. (12) and given in Table 6. By comparing between the actually obtained total heat flux and the ideal estimation with $\alpha_{2}=0.4$, the heat losses due to the entrapped air, leakages and edge effects would be more than $25 \%$ (as shown in Table 6). Therefore, the design improvement to reduce the heat losses was necessary to develop a practical collector design.

\subsection{Relation between the absorptivity and efficiency of the solar collector}

The most important aspects in the design of solar collector are the efficiency of the collector and the available water outlet temperature. Using the heat transfer analysis, the available water outlet temperature of the solar collector was estimated. For the given dimensions of the first prototype, the base properties given in Table 5 and the operating conditions of $\mathrm{T}_{\mathrm{a}}=\mathrm{T}_{\mathrm{in}}=20^{\circ} \mathrm{C}$, the achievable water outlet temperature and efficiency of the solar collector were calculated and presented in Table 7. The maximum water temperature rise and efficiency were $4.2{ }^{\circ} \mathrm{C}$ and 0.447 , respectively. It can be seen that the temperature of the absorber $\left(T_{2}\right)$ increased as the inlet water temperature $\left(T_{i n}\right)$ increased. As aforementioned, the larger temperature difference between the solar collector and the ambient resulted in the larger heat losses. Therefore, the achievable temperature rise and efficiency decreases as the inlet water temperature increased.

The estimated efficiencies were compared with the first prototype measurement and the reference of a 
conventional glazed flat plate solar collector with moderately selective black paint absorber in Fig. 9. The slope of the efficiency curve represents the rate of heat losses of the solar collector. The larger slope of the measured efficiency (Test 1 in Fig. 9) than that of the predicted efficiency (HT1 in Fig. 9) meant that the actual heat losses in the test were larger than those of the heat transfer calculation. It was attributed to the approximations of heat transfer modelling, such as neglecting the natural convection loss above the glazing cover and the edge effect. However, the heat transfer analysis reasonably predicted the relations between the collector design parameters and the collector performance.

The maximum efficiency with the base properties (HT 1 in Fig. 9) was much lower than the reference value. As aforementioned, the maximum efficiency of the collector firstly relies on the optical properties of the materials. In order to achieve a comparable efficiency with the reference value, a higher solar absorptivity of the absorber material was required. To achieve efficiency as high as the reference, the required solar absorptivity of the PC+CNT material was estimated by using the heat transfer analysis. The required higher optical properties are also provided in Table 5. Under the same dimensions and operating conditions with the higher absorptivity value of $\alpha_{2}=0.56$, the higher water outlet temperature and higher efficiency could be achieved as shown in Table 8. The maximum efficiency for the absorber of $\alpha_{2}=0.56$ was around 0.63. The higher efficiency (HT 2 in Fig. 9) with the higher absorptivity became comparable to the reference. Secondly, in order to increase the available water outlet temperature, the total heat gain needed to be increased by increasing the panel size.

Table 7

Estimated base temperatures and efficiency of the PC $+\mathrm{CNT}$ collector by heat transfer modelling.

\begin{tabular}{llllll}
\hline \hline $\mathrm{T}_{\mathrm{a}}\left({ }^{\circ} \mathrm{C}\right)$ & $\mathrm{T}_{\text {in }}\left({ }^{\circ} \mathrm{C}\right)$ & $\mathrm{T}_{\text {out }}\left({ }^{\circ} \mathrm{C}\right)$ & $\begin{array}{l}\mathrm{q}_{\text {total }}\left(\mathrm{W} / \mathrm{m}^{2}\right) \\
\text { to water }\end{array}$ & $\mathrm{T}_{2}\left({ }^{\circ} \mathrm{C}\right)$ & Efficiency \\
\hline 20 & 20 & 24.2 & 373 & 25.4 & 0.447 \\
20 & 25 & 29.0 & 355 & 29.2 & 0.425 \\
20 & 30 & 33.7 & 328 & 34.8 & 0.393 \\
20 & 35 & 38.4 & 302 & 39.4 & 0.361 \\
\hline \hline
\end{tabular}

(for $0.5 \mathrm{~m} \times 0.5 \mathrm{~m}$ panel with the base property value, $\alpha_{2}=0.4$, in Table 5 )

Table 8

Estimated higher temperatures and efficiency of the PC+CNT collector by heat transfer modelling.

\begin{tabular}{llllll}
\hline \hline $\mathrm{T}_{\mathrm{a}}\left({ }^{\circ} \mathrm{C}\right)$ & $\mathrm{T}_{\text {in }}\left({ }^{\circ} \mathrm{C}\right)$ & $\mathrm{T}_{\text {out }}\left({ }^{\circ} \mathrm{C}\right)$ & $\begin{array}{l}\mathrm{q}_{\text {total }}\left(\mathrm{W} / \mathrm{m}^{2}\right) \\
\text { to water }\end{array}$ & $\mathrm{T}_{2}\left({ }^{\circ} \mathrm{C}\right)$ & Efficiency \\
\hline 20 & 20 & 25.9 & 524 & 27.1 & 0.627 \\
20 & 25 & 30.7 & 506 & 30.9 & 0.606 \\
20 & 30 & 35.4 & 479 & 36.4 & 0.574 \\
20 & 35 & 40.1 & 453 & 40.3 & 0.542 \\
\hline \hline
\end{tabular}

(for $0.5 \mathrm{~m} \times 0.5 \mathrm{~m}$ panel with the higher property value, $\alpha_{2}=0.56$, in Table 5) 


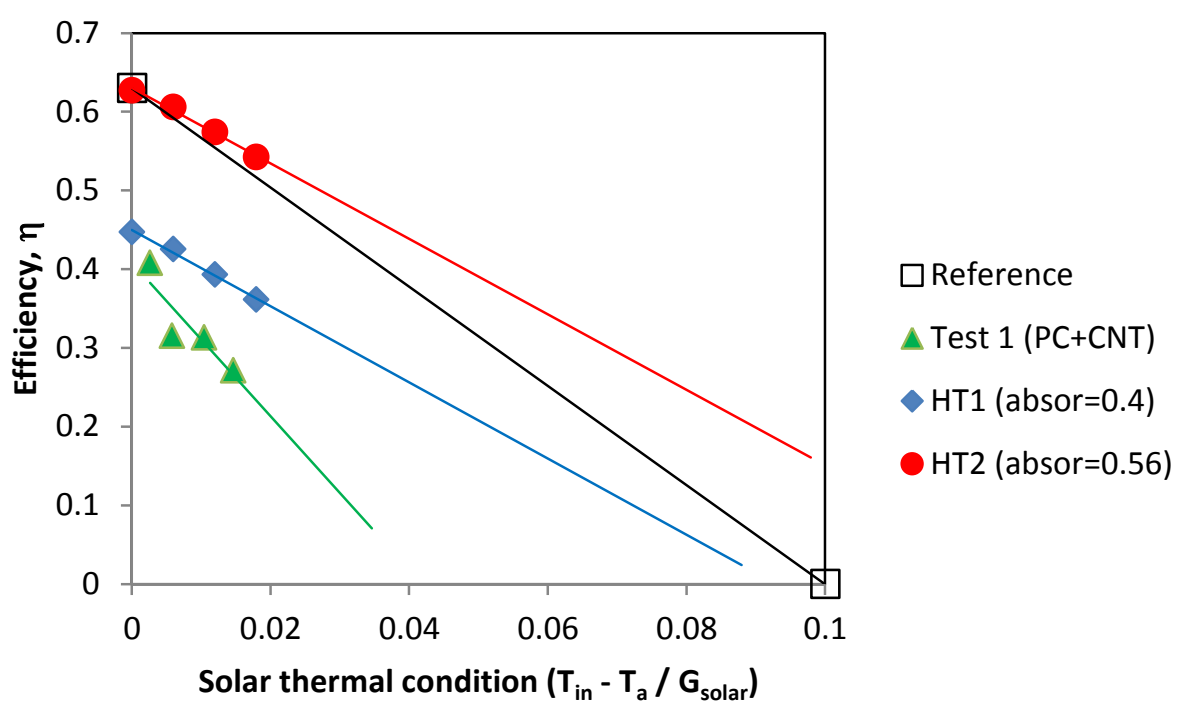

Fig. 9. The efficiency of the solar collector with different absorptivities $(0.5 \times 0.5$ panel $)$.

Table 9

Estimated temperatures and efficiency of the $\mathrm{PC}+\mathrm{CNT}$ collector with a longer size.

\begin{tabular}{llllll}
\hline \hline $\mathrm{T}_{\mathrm{a}}\left({ }^{\circ} \mathrm{C}\right)$ & $\mathrm{T}_{\text {in }}\left({ }^{\circ} \mathrm{C}\right)$ & $\mathrm{T}_{\text {out }}\left({ }^{\circ} \mathrm{C}\right)$ & $\mathrm{q}_{\text {total }}\left(\mathrm{W} / \mathrm{m}^{2}\right)$ to water & $\mathrm{T}_{2}\left({ }^{\circ} \mathrm{C}\right)$ & Efficiency \\
\hline 20 & 20 & 36.2 & 479 & 36.4 & 0.574 \\
20 & 25 & 40.3 & 453 & 40.3 & 0.542 \\
20 & 30 & 44.1 & 417 & 44.4 & 0.499 \\
20 & 35 & 48.0 & 384 & 48.2 & 0.461 \\
\hline \hline
\end{tabular}

(for $0.5 \mathrm{~m} \times 1.5 \mathrm{~m}$ panel with the higher property value, $\alpha_{2}=0.56$, in Table 5)

\subsection{Effect of the size of the solar panel}

In this section, the effects of the length of the solar collector on the thermal performance were computed with the higher optical properties in Table 5. For the given values of the material properties and the collector dimensions, the maximum achievable outlet temperatures of the water were estimated in the former section. As a result, the temperature of the water outlet was limited by the total heat gain which was depending on the optical properties of the material as well as the size of the solar collector. In order to increase the available water temperature of the solar collector under the fixed material properties, the size of the collector needed to be increased. In order to understand the effect of the panel size, the performance of a solar panel, which was three times longer than the first prototype collector, was calculated. The predicted results are provided in Table 9. The maximum temperature increment was around $16{ }^{\circ} \mathrm{C}$. It is reasonably close to the maximum rise of this type of the solar collector with the high flow rate (Ladener and Spate, 2008). The hot water over $60{ }^{\circ} \mathrm{C}$ could be achieved through the sequential connection of three solar collectors. The heat transfer between the absorber and the transfer medium, water, is proportional to the temperature difference between them. The temperature difference between the absorber and the water decreased as the water inlet temperature increased. As a result, the temperature increment decreased as the water inlet temperature, $T_{\text {in }}$, increased (as shown in Table 9).

The effect of the panel length on the efficiency of the solar collector was compared in Fig. 10. When 
the length of the collector doubles, the incoming solar radiation doubles too, thus the absorber receives twice energy. However, the collector efficiency is determined by the ratio between the incoming solar radiation and the absorbed energy. Figure 10 demonstrates that the collector's length does not have an influence on the efficiency of the solar collector. On the contrary, the efficiency of the longer panel (HT3 in Fig. 10) was lower than that of the smaller panel. Also, the efficiency curve of the longer panel (HT3 in Fig. 10) had larger slope than that of the smaller panel (HT2 in Fig. 10). It was attributed to the increased average temperature of the collector, resulting in the larger heat losses. These trends are consistent with the polymer solar collector analysis of Mintsa Do Ango et al. (2013).

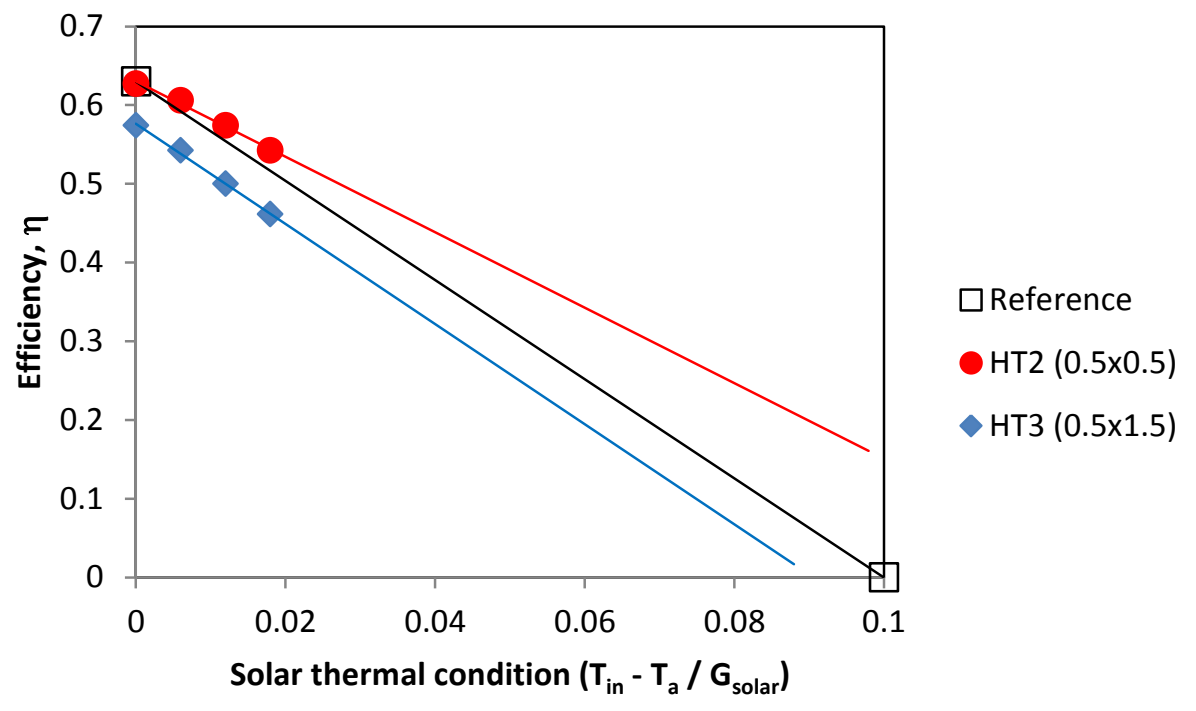

Fig. 10. The efficiencies of the solar collector with different sizes $\left(\alpha_{2}=0.56\right)$.

\section{Test of the Second Prototype}

\subsection{Construction of the second prototype}

The detrimental effects on the collector performance in the first prototype test were extensively observed and analyzed in the former sections. The design improvement for the second prototype was carried out; with the aim of reducing the edge effect and increasing the available water outlet temperature, the size of the second collector was elongated to $1500 \mathrm{~mm} \times 500 \mathrm{~mm}$. The smooth reflective finish of the CNT impregnated polycarbonate sheet was abraded to reduce the reflectivity and increase the absorptivity of its upper surface. Trapped air was identified as an issue in the first test, with a potential negative impact on the performance. The mounting for the solar collector was redesigned to include a fixed inclination of 0.8 degrees. The inclination of the collector would encourage air bubbles in the circulating fluid to accumulate in the uppermost manifold and prevent air pockets from gathering underneath the solar absorbing panel. The manifolds were adapted to incorporate automatic air eliminator vents that would allow any accumulating air from the circulating fluid to be vented out. The new manifold with an air bleed valve is shown in Fig. 11. The basic structure of the collector (in Fig. 2) and the production method of the materials were kept. Lastly, the collector was encased in a wooden frame to ensure protection for the second prototype and provide adequate structural rigidity to prevent flexing during transportation and installation (shown in Fig. 12). 


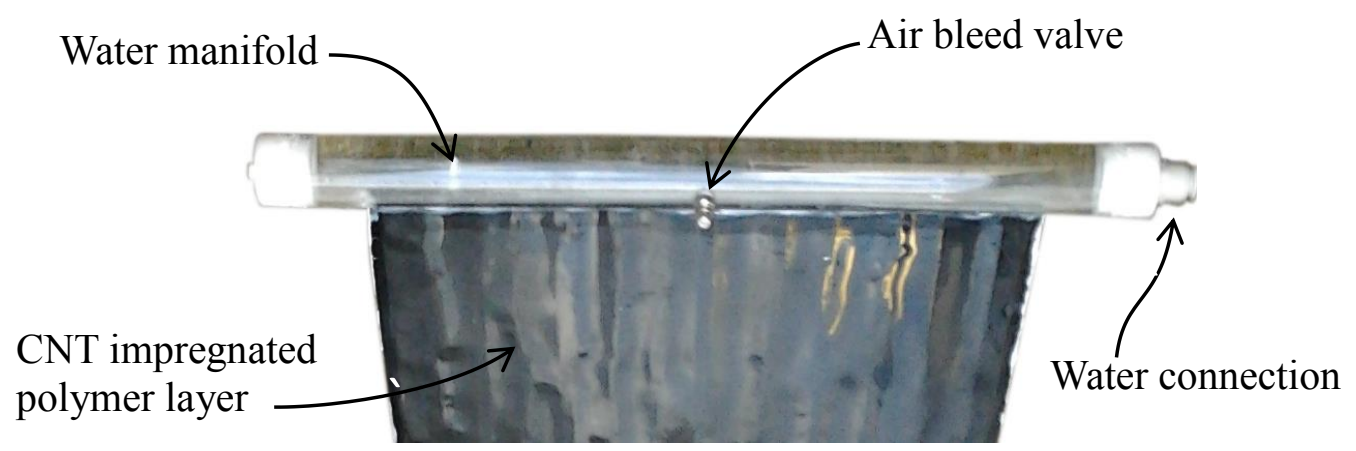

Fig. 11. Manifold of Phase 2 prototype with air vent fitted.

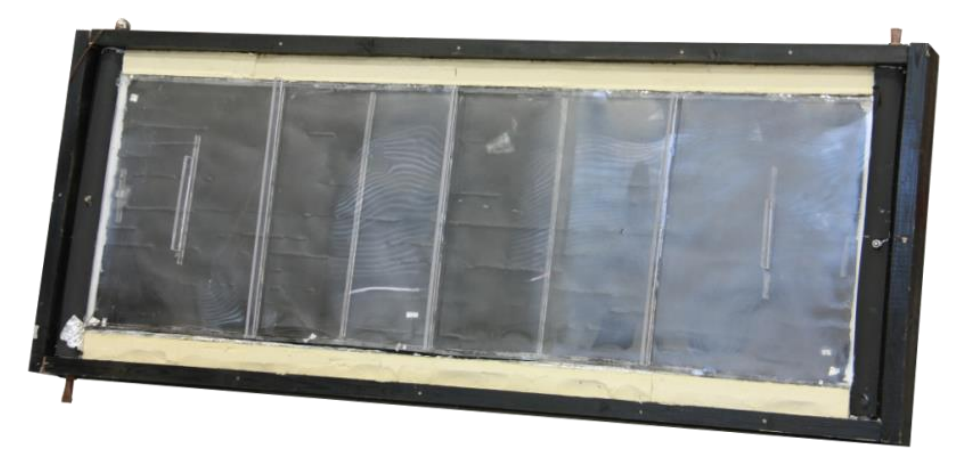

Fig. 12. The second prototype of the proposed PC+CNT solar collector.

\subsection{Performance of the second prototype}

The test of the second prototype collector $(1500 \mathrm{~mm} \times 500 \mathrm{~mm})$ using the same state-of-the-art indoor solar simulator facility at University of Ulster was conducted at a series of increasing inlet water temperature while measuring the energy absorption of the collector. The experimental set up and test method were basically identical to the case of the first test. The second test conditions were also set to be broadly comparable to the testing standards of BS EN 12975-2:2006. The solar simulated irradiance level was $800 \pm 5 \mathrm{~W} / \mathrm{m}^{2}$. The water flow rate of $0.99 \pm 0.2 \mathrm{l} / \mathrm{min}$ was maintained. This test condition of the flow rate, $79.21 /\left(\mathrm{h} \mathrm{m}^{2}\right)$, kept belonging to the same solar collector type of the high working fluid rate and relatively small temperature increase (Ladener and Spate, 2008). The initial inlet water temperature was $23{ }^{\circ} \mathrm{C}$, which was equal to the ambient temperature. The inlet water temperature was then increased by $5{ }^{\circ} \mathrm{C}$ intervals once the outlet water temperature reached a steady state condition.

The thermal efficiency curve of the solar collector performance is an important physical property of a solar collector. The comparative thermal efficiencies of the tested prototype solar collectors and the mathematical predictions are presented in Fig. 13. It can be seen that the performance of the second PC+CNT collector (Test 2 in Fig. 13) was significantly improved from those of the collectors in the first test. Furthermore, the developed $\mathrm{PC}+\mathrm{CNT}$ solar collector performed equivalently to the reference of the conventional glazed flat plate solar collector with moderately selective black paint absorber. The higher efficiency of the second $\mathrm{PC}+\mathrm{CNT}$ solar collector confirmed the successful design 
improvements through the first test and heat transfer analysis. Reducing the reflection and increasing the absorption of the absorber surface by the finish treatment resulted in the increase of the maximum efficiency of the second PC+CNT collector. The slope of the second PC+CNT collector's efficiency is smaller than that of the first PC+CNT collector. It was attributed to the decrease of the heat losses by avoiding the entrapped air and reducing the edge effect. Eventually, the polymer-carbon nanotubes based solar collector which has a comparable efficiency with a conventional solar collector has been successfully developed.

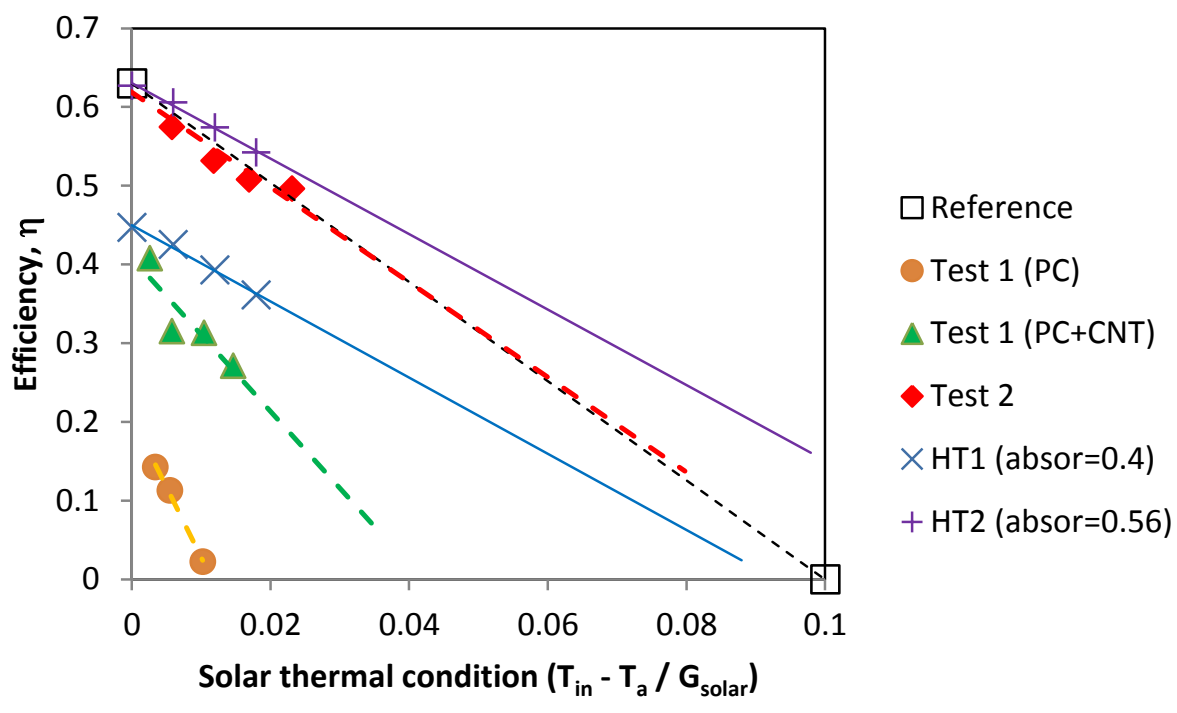

Fig. 13. The tested and estimated efficiencies of the solar collectors.

\section{Conclusion}

In this paper, the design and performance analysis of a polymer flat plate solar collector has been presented. The goal was to develop a low-cost, polymer flat plate solar collector, which has comparable performance to a conventional flat plate solar collector. For cost-effective manufacturing, low-cost, widely available and recyclable polymer materials were considered for the glazing and absorber layers of the collector. In order to improve the thermal and optical properties of the polymers, the carbon nanotubes (CNT) were impregnated into the polycarbonate (PC). The experimental test results showed that the inclusion of CNT played an important role in the efficiency of the polymeric absorber and improved significantly the thermal performance of the polymer solar collector.

A mathematical heat transfer modelling suitable for the investigation of the relations between the performance and the design parameters was also developed. Through the heat transfer analysis, the performance and characteristics of the polymer solar collector were estimated. The predictions of the present model fairly matched the measurements of the prototypes and were consistent with other researches. The analysis showed that increasing the length of the PC+CNT solar collector has no effect on the thermal efficiency of the collector, however, increases the available water outlet temperature. Also, it has been shown that the optical properties of the absorber material and the water inlet temperature are the key parameters to influence the thermal efficiency of the collector performance. 
A polymer-carbon nanotubes (CNT) based flat plate solar collector was designed with considering cost-effective manufacturing. The prototypes of the PC+CNT solar collector were built and tested at a state-of-the-art solar simulator facility at University of Ulster to evaluate their actual performance. Through the tests and analysis, the design improvement was carried out; the finish treatment to improve the optical properties of the absorber surface, the modifications of manifold and mounting to decrease the heat losses by avoiding the entrapped air and reducing the edge effect. Finally, a good thermal efficiency, which is close to the practical maximum of this type (a glazed flat plate) of solar collectors, was achieved. As a future step, the design optimization of the proposed polymer+CNT solar collector is to be investigated, in order to design more economically competitive thermal solar collectors for mass production.

\section{Nomenclature}

$$
\begin{array}{ll}
A_{s} & \text { area of collector } \\
c_{p} & \text { specific heat at constant pressure } \\
g & \text { gravitational acceleration } \\
G_{\text {solar }} & \text { solar intensity } \\
H_{1} & \text { air gap height } \\
k & \text { conductivity } \\
\dot{m} & \text { mass flow rate } \\
q & \text { heat flux } \\
Q & \text { heat transfer rate } \\
T & \text { Temperature } \\
\alpha & \text { absorptivity } \\
\beta & \text { coefficient of volume expansion } \\
\varepsilon & \text { emissivity } \\
\eta & \text { solar collector efficiency } \\
v & \text { kinematic viscosity } \\
\sigma & \text { Stefan-Boltzmann constant } \\
\tau & \text { transmissivity } \\
\mathrm{CNT} & \text { carbon nanotubes } \\
\mathrm{PC} & \text { polycarbonate } \\
\hline
\end{array}
$$

Subscripts
a ambient
conv convection 
$\begin{array}{ll}\text { in } & \text { inlet } \\ \text { out } & \text { outlet } \\ \text { rad } & \text { radiation }\end{array}$

\section{References}

Abtahi, A., 1993. Low-cost solar water heating: the breadbox heater made with recycled plastics, Proceedings I.S.E.S. Solar World Conf., 5, 347-352.

Cengel, Y. And Ghajar, A., 2011. Heat and mass transfer: Fundamentals \& applications, 4th Ed., McGraw-Hill.

Chen, G., Doroshenko, A., Koltun, P., Shestopalov, K., 2015. Comparative field experimental investigations of different flat plate solar collectors, Solar Energy, 115, 577-588.

Cristofari, C., Notton, G., Poggi, P., Louche, A., 2002. Modelling and performance of a copolymer solar water heating collector, Solar Energy, 72, 99-112.

Dorfling, C., Hornung, C.H., Hallmark, B., Beaumont, R.J.J., Fovargue, H., Mackley, M.R., 2010. The experimental response and modelling of a solar heat collector fabricated from plastic microcapillary films. Solar Energy Materials \& Solar Cells. 94, 1207-1221.

Ebadi-Dehaghani, H., Nazempour, M., 2012. Thermal conductivity of nanoparticles filled polymers, 519 - 540, Smart Nanoparticles Technology, Abbass Hashim (Ed.), In Tech.

Hollands, K., Unny, T., Raithby, G., Konicek, L., 1976. Free convective heat transfer across inclined air layers, Journal of Heat Transfer, 98, 182-193.

Hossain, M, Saidur, R., Fayaz, H., Rahim, N., Islam, M., Ahamed, J., Rahman, M., 2011. Review on solar water heater collector and thermal energy performance of circulating pipe, Renewable and Sustainable Energy Reviews, 15, 3801-3812.

IRENA, 2014, REmap 2030 A Renewable Energy Roadmap, http://irena.org/remap/IRENA REmap Report June 2014.pdf (September 2015)

Kudish, A. I., Evseev, E. G., Walter, G. Leukefeld, T., 2002. Simulation study of a solar collector with a selectively coated polymeric double walled absorber plate, Energy Conversion \& Management, 43, 651-671.

Ladener, H., Spate, F., 2008. Solaranlagen: Das Handbuch der thermischen Solarenergienutzung. Okuboch-Verlag, Staufen, ISBN 978-3-936896-40-4.

Mark, J. E., 2007. Physical Properties of Polymers Handbook, Springer.

Martinopoulos, G., Missirlis, D., Tsilingiris, G., Yakinthos, K., Kyriakis, N., 2010, CFD modeling of a polymer solar collector, Renewable Energy, 35, 1499-1508.

Mintsa Do Ango, A., Medale, M., Abid, C., 2013., Optimization of the design of a polymer flat plate solar collector, Solar Energy, 87, 64-75.

Missirlis, D., Martinopoulos, G., Tsilingiridis, G., Yakinthos, K., Kyriakis, N., 2014. Investigation of the heat transfer behaviour of a polymer solar collector for different manifold configurations, Renewable Energy, 68, 715-723.

Nanocyl S. A., Belgium, 2015. http://www.nanocyl.com/ (September 2015)

Potschke, P., Bhattacharyya, A. R., Janke, A., 2003. Morphology and electrical resistivity of melt mixed blends of polyethylene and carbon nanotube filled polycarbonate, Polymer. 44, 80618069.

REN21, 2015. Renewables 2015 Global Status Report, http://www.ren21.net/GSR-2015-Report-Fullreport-EN (September 2015) 
Smyth, M., Zacharopoulos, A., Mondol, J. D., 2013. Performance evaluation of the Lawell carbon nano-tube (CNT) polycarbonate solar water heating collector, Report for Lawell Asphalt, the Centre for Sustainable Technologies, University of Ulster.

Tsilingiris, P.T., 1997. Design, analysis and performance of low-cost plastic film large solar water heating systems. Solar Energy. 60, 245-256.

Tsilingiris, P.T., 1999. Towards making solar water heating technology feasible - the polymer double walled absorber plate. Energy Conversion \& Management. 40, 1237-1250.

Wijeysundera, N.E., Iqbal, M., 1991. Effect of plastic cover thickness on the top loss coefficient of FPSCs. Solar Energy, 2, 83-87.

Zacharopoulos, A., Mondol, J. D., Smyth, M., Hyde, T., O’Brien, V., 2009. State-of-the-art solar simulator with dimming control and flexible mounting. In: Proceedings of the ISES Solar World Congress 2009, 11 - 14 October, Johannesburg, South Africa, pp. 854-863. 